\title{
Rating estimation of sustainability in the construction of high-rise building
}

\author{
Svetlana Sheina ${ }^{1}$, Vladimir Belash ${ }^{1}$, Vera Ulianskaia ${ }^{1, *}$ \\ ${ }^{1}$ Don State Technical University, Socialisticheskaya 162a, Rostov-on-Don, Russia
}

\begin{abstract}
The paper presents an assessment of a unique high-rise building according to the environmental certification system STO NOSTROY 2.35.4-2011 (Russia). Certification system of sustainable environment is described with the estimated criteria. An assessment of the existing European high-rise building adapted to the regional conditions of Rostov-on-Don in accordance with the specified standard was made. Result of preliminary assessment of building is shown. And the building parameters, work with which could increase the overall rating of certification, are emphasized.
\end{abstract}

\section{Introduction}

The problem of sustainable development of territories, cities and objects has been acute for several decades. The first discussion of the concept took place in 1972 at the UN conference in Stockholm [1]. Currently, the United Nations has developed a detailed program for achieving sustainable development of the planet [2], which includes 17 tasks: the fight against poverty, hunger, inequality, rational consumption and resource extraction, provision of clean ecological energy, construction of sustainable cities, and others.

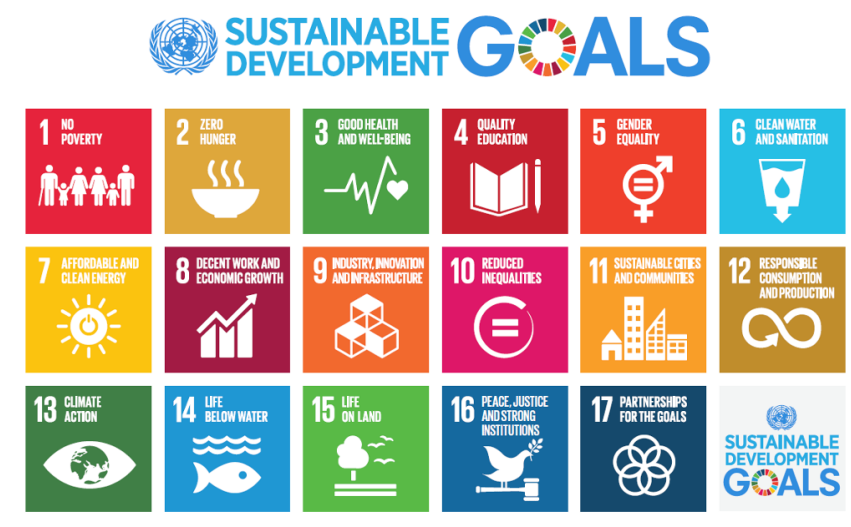

*Correspondent author: vera@uliansky.com 
Fig. 1. Sustainable development achievement purposes of society and planet [3].

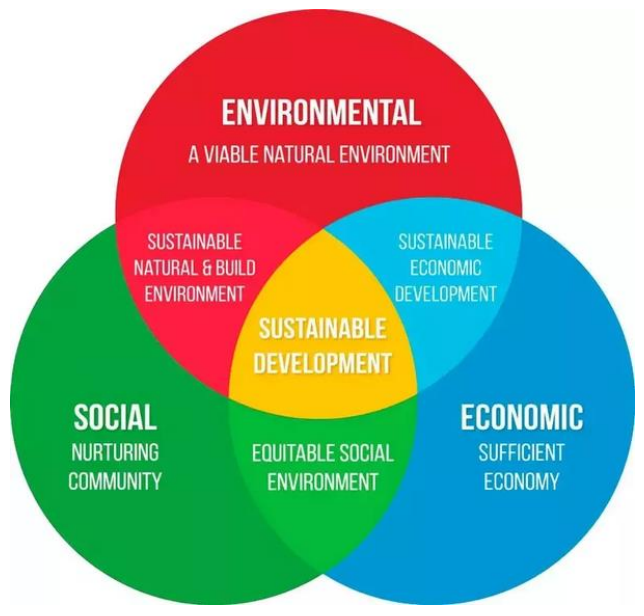

Fig. 2. Constituted elements of sustainable development [4].

\section{Materials and methods}

Sustainable urban development undoubtedly implies sustainable construction of urban facilities. In megacities great attention is paid to the construction of high-rise buildings, which are the center of large corporations and offices. In connection with the consumption of a large amount of resources and electricity, high-rise buildings should comply with existing environmental requirements and standards as much as possible. Studies have shown that the following factors have an influence on green high-rise construction [5,6] (Fig. 3.):

1) renewable energy resources use;

2) eco-friendly materials use;

3) innovative technologies implantation;

4) resource saving;

5) consumption control with Smart house system, and others.

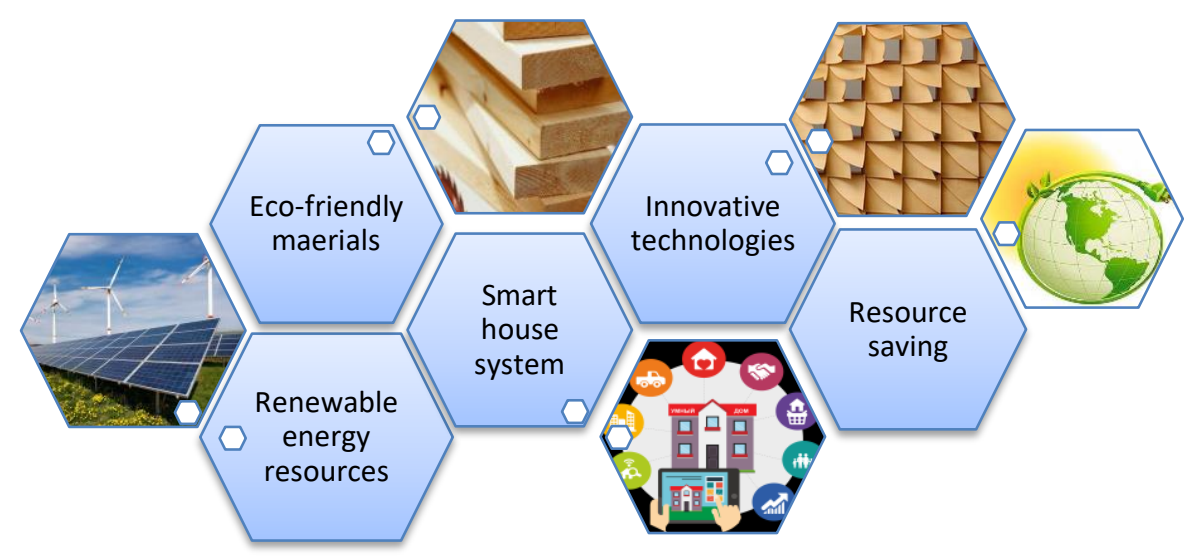

Fig. 3. Factors affecting energy efficient construction [7].

The need to take into account these factors to create a healthy human environment in an urban environment has led to the creation of various environmental certification systems, of which 
the BREEAM (UK) [8] and LEED (USA) [9] assessment systems are the most common at present. Evaluation is carried out according to various criteria. For example, LEED takes into account the particularities of the region and the internal environment of the structure, while BREEAM emphasizes environmental preservation and waste disposal. The general criteria for assessing [10,11] (Fig. 4.) are highlighted:

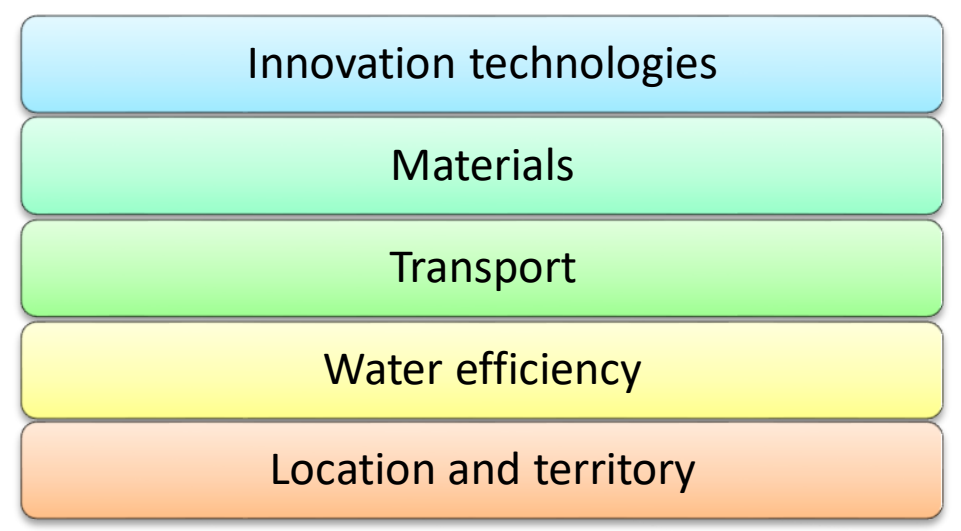

Fig. 4. Ecological assessment criteria accountable by BREEAM and LEED.

In Russia, there are several certification systems with green standards [12] that differ by assessment categories, normative bases and evaluation methods. One of them STO NOSTROY 2.35.4-2011, which estimates construction project on 46 parameters, united to 10 categories. This system matches with international standards ISO and takes into consideration key aspects of BREEAM, LEED, DGNB (Germany), and HQE (France) certification systems. Certification could be made both for finished and reconstructed residential and public buildings. Factor of construction object sustainability (S-factor) is a result of all parameters point summation. In accordance with S-factor sustainable environment assessment class has to be assigned. This paper has been developed foe regional characteristics of Moscow city and Moscow region. In the need of evaluation of the construction object in other regions, additional document has been input, that corrects number of categories the significance of which is a variable quantity, and taking into account the peculiarities of the territory in which the objects are certified [13]. The assessment of the building according to this document is implemented on the example of residential high-rise building Bosco Verticale ("Vertical Forest") Torre E [14] built in Milan in 2008, that is adapted for territorial conditions of Rostov region. Unique building with a height of 111 meters is designed by architect Stefano Boeri and has a worldwide fame due to bushes, scrubs and trees with the height up to 9 meters $[15,16]$ located on balconies of the tower all around, creating peculiar forest across the height of the building. "Vertical Forest" has a Gold certificate by LEED.

For certification by STO NOSTROY 2.35.4-2011 it is necessary to calculate number of points by each category of evaluation. Several parameters of the certification could not be computed accurately on preinvestment stage because the construction is not finished. Concerning this fact, points of selected sustainability of environment level evaluation has been taken preliminarily. Data are summarized in Table 1.

Table 1. Number of points by categories of STO NOSTROY 2.35.4-2011.

\begin{tabular}{|c|c|c|c|}
\hline Name of criterion & $\begin{array}{c}\text { Maximal } \\
\text { estimated } \\
\text { score }\end{array}$ & $\begin{array}{c}\text { Category } \\
\text { proportion, } \\
\%\end{array}$ & $\begin{array}{c}\text { Obtained } \\
\text { score }\end{array}$ \\
\hline
\end{tabular}




\begin{tabular}{|l|c|c|c|}
\hline Maximal total score in rating system & 650 & 100 & 536.768 \\
\hline $\begin{array}{l}\text { Category 1 - Comfort and quality of } \\
\text { external environment }\end{array}$ & 70 & 10.8 & 45 \\
\hline $\begin{array}{l}\text { Category 2 - Architectural and } \\
\text { planning quality }\end{array}$ & 60 & 9.2 & 56 \\
\hline $\begin{array}{l}\text { Category 3 - Comfort and ecology of } \\
\text { internal environment }\end{array}$ & 86 & 13.3 & 81 \\
\hline $\begin{array}{l}\text { Category 4 Quality of sanitary } \\
\text { protection and recycling }\end{array}$ & 25 & 3.9 & 20 \\
\hline Category 5 - Efficient water use & 40 & 6.1 & 36 \\
\hline $\begin{array}{l}\text { Category 6 - Energy saving and } \\
\text { energy efficiency }\end{array}$ & 60 & 18.5 & 88,3 \\
\hline $\begin{array}{l}\text { Category 7 - Alternative and } \\
\text { renewable energy use }\end{array}$ & 64 & 9.8 & 38 \\
\hline $\begin{array}{l}\text { Category 8 - Ecology of design, use } \\
\text { and disposal of construction object }\end{array}$ & 65 & 10 & 63 \\
\hline Category 9 - Economic efficiency & 60 & 9.2 & 46 \\
\hline $\begin{array}{l}\text { Category 10 - Quality of preparation } \\
\text { and management of the project }\end{array}$ & & & \\
\hline
\end{tabular}

For resulting S-factor an additional calculation of regional coefficients by criteria27-29 (category 5), 30, 32 (category 6), 35 (category 7), 40, 41 (category 9), and also reduced Sfactor is necessary [17], with the clause of object location is in Rostov region.

Table 2. Adjustable regional coefficients.

\begin{tabular}{|l|l|l|l|l|l|l|l|l|l|l|l|}
\hline \multicolumn{2}{|l|}{ Parameter } & $27-29$ & 30 & 32 & 35 & 40 & 41 & $K_{\text {red }}$ \\
\hline $\begin{array}{l}\text { Adjustable } \\
\text { regional } \\
\text { coefficient }\end{array}$ & 0.9 & 0.9 & 1.3 & 0.8 & 0.9 & 1.0 & 1.06 & & & & \\
\hline
\end{tabular}

Fig. 5. Environmental sustainability classes of STO NOSTROY 2.35.4-2011 [17].

\begin{tabular}{|c|c|c|c|c|c|c|c|}
\hline $\begin{array}{l}\text { S-factor, } \\
\text { score }\end{array}$ & $520-650$ & $420-519$ & $340-419$ & $260-339$ & $170-259$ & $100-169$ & $0-99$ \\
\hline $\begin{array}{l}\text { Evaluation } \\
\text { classes }\end{array}$ & A & B & C & D & $\mathrm{E}$ & F & $\mathrm{G}$ \\
\hline $\begin{array}{l}\text { Evaluation } \\
\text { marks }\end{array}$ & & & & & & & \\
\hline & & & & 10 & $\mathbf{E}$ & $\mathbf{F}$ & $G$ \\
\hline & & & & & & & \\
\hline
\end{tabular}

\section{Results and discussion}


In accordance with calculated value of S-factor, this object has A-category $(536,768)$, which is the highest estimated environmental sustainability class in mentioned certification system. However, with analysis of the table it is seen to be necessary to introduce additional systems and technologies by selected parameters for the highest score achievement. Thus, they should take action for increasing reclamation percentage up to 70 per cent, whereas in mentioned project process works just for 20 per cent. It is important to consider location of the building and environment. Inquired building does not have any artificial or natural water resources, and this fact reduces the visual comfort. Moreover, there were not envisaged to place any fitness grounds in the house area.

\section{Conclusions}

Thus, ecological standard certification of construction objects let to notice, what parameters effect on achievement of construction object sustainability, and what aspects are necessary to admit during design and construction process for the most energy efficient solution. Moreover, estimation process contributes the professional development and advance of competitiveness level among the design institution.

\section{References}

1. Report of the United Nations Conference on the human environment, 80 (1972)

2. Sustainable Development Goals. United Nations.

3. Official United Nations website. Sustainable development goals.

4. A. Sentana, S. Valero, E. Velasco, C. Senabre, Sustainability as a Paradigm of Energy Policy. ICREPQ (2016)

5. Yu. Tabunshchikov, A. Naumov, Yu. Miller, Energy efficient criteria in green construction. Energosberezheniye, 1 (2012)

6. S. Sheina, V. Ulianskaya, Factors of ecological high-rise buildings research. Modern condition and developmet perspectives, 27-34 (2017)

7. S. Sheina, I. Zilberova, V. Kasyanov, Fedorovskaya, A. Sustainable development of territories, cities and companies. Study DSTU (2018)

8. Official BREEAM website. How BREEAM certification works.

9. Official LEED website.

10. S. Sheina, V. Ulianskaya, Modern ecological certification systems in construction in Russia and abroad. Construction and industrial safety 12(64), 23-28 (2018)

11. E. Sukhinina, General aspects and international ecological standards comparison in construction. Vestnik Saratov State Technical University 4(73), 209-215 (2013)

12. O. Klochkova, E Sukhinina, Problems of ecological building certification in Russia. Vestnik MGSU 4(103), (2017)

13. STO NOSTROY 2.35.68-2012. Regional features consideration in rating evaluation system of sustainable environment (2012)

14. Official website Stefano Boeri Architetti. Vertical Forest.

15. E. A. Giacomello, New Urban Forest Rises in Milan. Council on Tall Buildings and Urban Habitat Research Paper (2015) 
16. E. Giacomello, M. Valagussa, Vertical Greenery. Evaluating the High-Rise Vegetation of the Bosco Verticale, Milan. Council on Tall Buildings and Urban Habitat (2015)

17. STO NOSTROY 2.35.4-2011. Green construction. Residential and public buildings. Rating system for assessing environmental sustainability. 